\title{
VLOGA MAJHNIH OBČIN PRI RAZVOJU SLOVENSKEGA PODEŽELJA
}

\author{
Monika Benkovič Krašovec \\ Rakovniška I3, I292 Ig \\ e-mail: monika.benkovic@siol.net
}

Izvirni znanstveni čalnek

COBISS 1.01

\section{Izvleček}

Na podlagi prvega Zakona o lokalni samoupravi (1993) in Zakona o ustanovitvi občin in njihovih območij (1994) se je v letu 1994 oblikovalo 147 občin, do leta 2002 pa se je njihovo število povečalo na 193. Na novo so nastajale predvsem majhne občine, tudi takšne, ki niso izpolnjevale $\mathrm{v}$ zakonu določenih pogojev. Zato so potekale in še vedno potekajo številne razprave o učinkovitosti takšnih občin in smiselnosti nadaljnje delitve Slovenije. V letu 2005 je imelo 95 občin manj kot 5000 prebivalcev, kar je zakonsko določena meja za ustanovitev občine. Vse majhne občine smo anketirali in podali oceno o njihovem vplivu na razvoj podeželja.

Ključne besede: Slovenija, občine, razvojni problemi in potenciali, podeželje

\section{THE ROLE OF SMALL MUNICIPALITIES IN DEVELOPMENT OF RURAL AREAS IN SLOVENIA}

\begin{abstract}
On the basis of the first Local Self-Government Act (1993) and the Establishment of Municipalities and Municipal Boundaries Act (1994), 147 municipalities were created in 1994, till 2002 their number increased to 193. Most of the newly-founded municipalities were small, including municipalities that did not meet the conditions stipulated by law. Consequently, there have been many discussions on the efficiency of such municipalities and the reasonableness of any further division of Slovenia. In 2005, 95 municipalities had less than 5000 inhabitants, which is the legally prescribed threshold for the establishment of a municipality. Therefore, all these municipalities were surveyed and an assessment of their impact on the development of rural areas in Slovenia was given.
\end{abstract}

Key words: Slovenia, municipalities, developmental problems and potentials, rural areas 


\section{UVOD}

Ob osamosvojitvi leta 1991 je bila Slovenija razdeljena na 62 občin. S sprejetjem ustave in z novo zakonodajo je prišlo do njihovega preoblikovanja; občine so se začele deliti in leta 2005, ko je bila raziskava izvedena, je bilo v Sloveniji 193 občin. V prvi polovici leta 2006 jih je nastalo še 17. Novo nastale občine so večinoma majhne, nekatere komajda izpolnjujejo v Zakonu o lokalni samoupravi določene pogoje za ustanovitev občine.

Mnenja o nastanku majhnih občin so različna; nekateri menijo, da bodo morebitne nadaljnje spremembe $\mathrm{v}$ smeri povečevanja števila občin prispevale $\mathrm{k}$ slabitvi lokalne samouprave, spet drugi pa v njih vidijo enkratno priložnost za razvoj. »)Samostojnost, občutek odgovornosti za lastno usodo lahko spodbudi nov zagon v teh krajih, da krila gospodarskemu in socialnemu razvoju in oživi umirajoče kraje« meni Pečauer $(2006,1)$. S tem pa vpliva na razvoj po vsej državi. Kljub dejstvu, da je nastanek občine marsikje prinesel precejšen razvoj, je jasno, da so nekatere občine premajhne, da bi same zmogle večje investicije in izpeljale razvojne programe. To bo mogoče doseči z intenzivnejšim povezovanjem občin $v$ interesne zveze, v okviru katerih bodo skupaj zagotavljale opravljanje tistega dela svojih nalog, ki presega organizacijske, finančne in kadrovske sposobnosti posameznih občin. Slovenska lokalna samouprava se mora prilagoditi evropskim standardom. Svet Evrope - Kongres lokalnih in regionalnih oblasti Evrope meni o velikosti občin v Sloveniji, »da je zaželeno strožje izvajanje slovenskega Zakona o lokalni samoupravi, ki določa minimum 5000 prebivalcev za ustanovitev nove občine, in zaradi tega meni, da je bolje nehati ustanavljati nove občine, da se prepreči še večja razdrobljenost, združena z nezadostnim financiranjem « (Čokert, 2005, 214). Evropske države sicer poznajo zelo majhne občine, kakršne nastajajo tudi v Sloveniji, vendar imajo tudi vmesno stopnjo med občino in državo, t.i. pokrajine. Ustava sicer dopušča prostovoljno povezovanje občin v večje enote, vendar doslej do pokrajin ali kakšne podobne oblike povezovanja na celotnem območju Slovenije še ni prišlo.

\section{NAMEN RAZISKAVE IN METODA DELA}

Leta 2005 je bilo v Sloveniji 193 občin. Največja občina je bila Ljubljana z 265.881 prebivalci, najmanjša pa Osilnica z 332 prebivalci. Pod 1000 prebivalcev je imelo še pet občin, med 1.000 in 2.000 19, med 2.000 in 3.00022 ter med 3.000 in 5.00048 občin. Navedeni podatki kažejo na zelo velik razpon občin glede na število prebivalcev, čeprav ima vsaka izmed njih enake ali podobne naloge, kot jih navaja Zakon o lokalni samoupravi. Vendar velikost občin naj ne bi vplivala na njihovo učinkovitost pri izvajanju različnih nalog, kar kažejo uspešne ureditve v nekaterih evropskih državah, kjer so občine po številu prebivalcev tudi manjše (Demšar, 2004). Zaposleni na občinah morajo skrbeti za naloge, ki segajo na zelo različna strokovna področja. Velike občine lahko organizirajo delo in zaposlijo strokoven kader za vsako področje posebej, medtem ko si majhne občine tega ne morejo privoščiti. Prav zato jim je večkrat očitana nestrokovnost in neučinkovitost. 
$\mathrm{Z}$ analizo stanja na osnovi razpoložljivih statističnih in $\mathrm{z}$ anketo pridobljenih podatkov smo $\mathrm{s}$ pričujočo raziskavo želeli:

- evidentirati obstoječo opremljenost občin s storitvenimi dejavnostmi in komunalno infrastrukturo,

- ugotoviti, katere storitve in infrastruktura so nastale po oziroma zaradi ustanovitve občine,

- ugotoviti, katere razvojne aktivnosti so izvajale občine v preteklosti, katere izvajajo in katere bodo izvajale $\mathrm{v}$ prihodnjih letih,

- $\quad$ ugotoviti ključne probleme občin, njihove potrebe in razvojne možnosti,

- podati oceno o učinkovitosti lokalne samouprave v Sloveniji. Menimo namreč, da je ustanovitev številnih majhnih občin imela pozitiven učinek na razvoj velikega dela slovenskega podeželja, zlasti na manj razvitih in demografsko ogroženih območjih. Občine so tiste, ki bodo s primernim načrtovanjem in usmerjanjem razvoja najbolj vplivale na prihodnji razvoj slovenskega podeželja, saj so po 2. členu Zakona o spodbujanju skladnega regionalnega razvoja (Ur. 1. RS 90/2005) poleg države odgovorne za skladni regionalni razvoj, katerega del je tudi razvoj podeželja.

Anketni vprašalnik je bil v mesecu maju in juniju 2005 poslan 94. slovenskim občinam, ki so imele manj kot 5.000 prebivalcev, kar je zakonsko določena meja za ustanovitev občine. Vse občine pod to mejo smo šteli za majhne, saj so bile ustanovljene na osnovi posebnih kriterijev. Sprva je bilo določeno, da sme zaradi geografskih, obmejnih, narodnostnih, zgodovinskih ali gospodarskih razlogov občina imeti izjemoma tudi manj kot 5.000 prebivalcev (13. člen Zakona o lokalni samoupravi, Ur. 1. RS 72/1993). Zaradi velikega števila zelo majhnih občin je bilo leta 2005 dodano, da izjemoma ustanovljene občine ne smejo imeti manj kot 2.000 prebivalcev (4. člen Zakona o lokalni samoupravi, Ur.l. RS 72/2005). Anketa ni bila poslana občini Trzin, ki jo predstavlja le eno istoimensko naselje in katere precejšen del predstavlja industrijska cona. Poleg tega gre za izrazito suburbano območje Ljubljane z gosto poselitvijo, ki nima ključnih značilnosti podeželja.

Kljub večkratnim poskusom občine Divača, Dobrepolje in Razkrižje v anketi niso hotele sodelovati. Na vprašalnik je odgovorilo 91 občin.

V raziskavo vključene občine obsegajo $5.763 \mathrm{~km}^{2}$, kar je $28 \%$ slovenskega ozemlja. V njih je leta 2002 živelo 270.497 (13,7\%) prebivalcev.

\section{UPRAVNA RAZDELITEV SLOVENIJE}

Ob osamosvojitvi leta 1991 je bila Slovenija razdeljena na 62 občin. Takrat je imela povprečna slovenska občina 31.709 prebivalcev in $327 \mathrm{~km} 2$. Občine so predstavljale prvo stopnjo državne oblasti, zato so bile temeljne krajevne potrebe prebivalstva prenesene na 1.250 krajevnih skupnosti. Podeželske krajevne skupnosti so bile praviloma uspešnejše od mestnih, ker so bile bolj neposredno vpete v krajevne razmere in potrebe. Organizacijsko je bila takšna ureditev občin nekje med državno upravo in lokalno samoupravo. Naloge in dejavnosti so se med seboj prepletale in stanje ni ustrezalo niti standardom upravljanja državne uprave niti interesom lokalne samouprave. 
Slika 1: V raziskavo vključene občine.

Figure 1: Municipalities, which were included in the research.

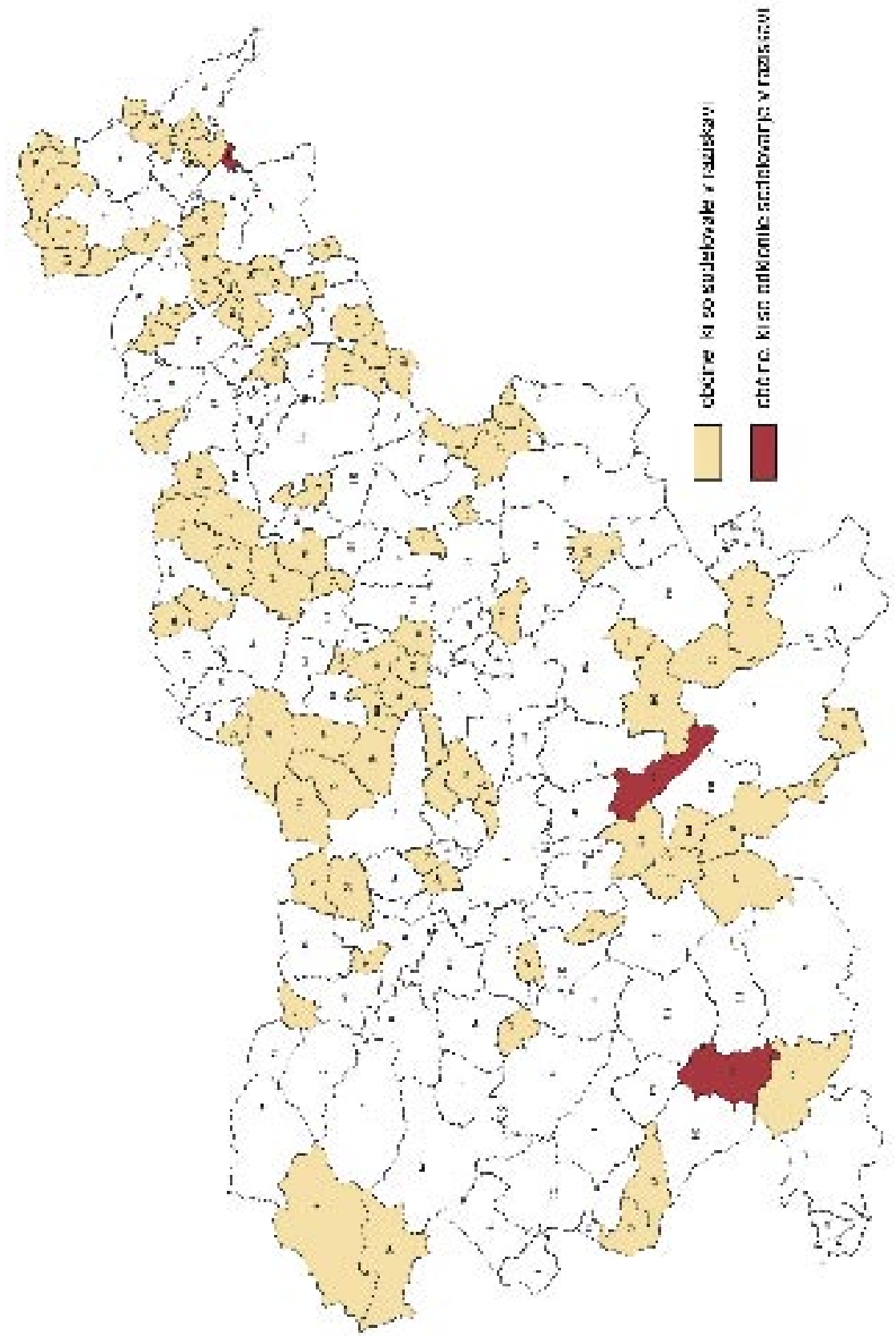


Z osamosvojitvijo Slovenije je bila sprejeta nova ustava, ki izrecno navaja občine kot obliko lokalne samouprave. Po ustavi občina obsega naselje ali več naselij, ki so povezana s skupnimi interesi in potrebami. Občina se ustanovi z zakonom po predhodnem referendumu, s katerim se ugotovi volja prebivalcev na določenem območju. Ustava predvideva tudi možnost prostovoljnega povezovanja občin v širše lokalne samoupravne skupnosti. V pristojnost občin sodijo krajevne zadeve. Po predhodnem soglasju občin lahko država nanje prenese opravljanje posameznih nalog iz pristojnosti države, če za to zagotovi potrebna sredstva (Pečar, 2002; Čokert, 2005).

Zakon o lokalni samoupravi je bil sprejet konec leta 1993 (Ur. 1. RS 72/1993), do oktobra 2005 pa je doživel že devet sprememb ali dopolnitev. Leta 1994 je bil sprejet Zakon o ustanovitvi občin in določitvi njihovih območij (Ur. 1. RS 60/1994, 69/1994), s katerim je bilo istega leta ustanovljenih 147 občin. Za območje ene ali več občin so bile organizirane upravne enote (58 upravnih enot), na katere so se zaradi večje racionalnosti in učinkovitosti prenesle določene naloge državne uprave. Povprečna občina je merila okrog $138 \mathrm{~km} 2$ in imela 13.374 prebivalcev. Temeljnih pogojev za ustanovitev občine ni izpolnjevala več kot polovica občin (Pečar, 2002).

Proces teritorialnega preoblikovanja državne uprave s tem še ni bil končan. Sledila je vrsta pritožb na ustavno sodišče in spomladi leta 1997 je stekel postopek za ustanovitev novih občin. Državni zbor je s spremembo Zakona o ustanovitvi občin in določitvi njihovih območij (Ur. 1. RS 56/1998, 75/1998) leta 1998 povečal število občin za 45 (Katalog regionalnih delitev, 2001). Na novo so nastale predvsem majhne občine, s čimer se je povprečna občina zmanjšala na $106 \mathrm{~km} 2$ in 10.341 prebivalcev (Pečar, 2002).

V letu 2002 je bilo podanih kar 50 predlogov za ustanovitev novih občin. Ob presoji upravičenosti predlogov so se strogo upoštevali kriteriji za oblikovanje novih občin (5.000 prebivalcev kot temeljno merilo za ustanovitev občine). Podatki o financiranju občin so namreč kazali, da so predstavljale občine z manj kot 5000 prebivalci finančno breme državi, ker so praviloma prejemale finančno izravnavo iz državnega proračuna. Na koncu so bili vsi predlogi za nove občine zavrnjeni, z izjemo občine Šmartno pri Litiji, ki se je odcepila od občine Litija in tako postala 193. občina v Sloveniji.

Oktobra 2005 je bilo državnemu zboru posredovanih še 34 predlogov za spremembe občin. Državni zbor je po obravnavi odločil, da izpolnjuje pogoje za ustanovitev občine 15 predlogov. Po izvedenih referendumih konec januarja 2006 je dobilo podporo volivcev 12 predlogov (Taškar, 2006). Na začetku aprila je potekalo še sedem referendumov, ki jih je omogočilo ustavno sodišče $\mathrm{z}$ odločbo, da državni zbor ni ravnal prav, ko je v prvem krogu zavrnil predloge za ustanovitev novih občin zaradi odsotnosti zdravstvene ustanove. Izidi referendumov so potrdili nastanek še petih novih občin (sprejeti jih mora še državni zbor), tako da bomo leta 2007, ko bodo nove občine zaživele, imeli v Sloveniji že 210 občin (Taškar, 2006a).

Velik interes po ustanavljanju novih občin kaže, da trenutna urejenost lokalne samouprave ni najbolj primerna in zadovoljiva, lokalno prebivalstvo pa kljub deklarirani pomembnosti nima dovolj velikega vpliva pri odločanju in reševanju svojih problemov. Majhne občine so očitno uspešne v zadovoljevanju potreb svojih občanov, čeprav obstaja mnenje, da jim gre dobro samo zato, ker dobivajo več denarja iz državne blagajne. Nasprotniki nastanka novih občin 
trdijo, da gre za prelivanje denarja $\mathrm{v}$ okolja, ki se sama niso sposobna postaviti na noge in da bo težnja ustanavljanja novih občin ustavljena šele takrat, ko se bo spremenil sistem financiranja občin. Veljavna zakonodaja o financiranju občin še vedno spodbuja nastanek majhnih občin, ki si denarja za svoje nemoteno osnovno delovanje ne zagotavljajo same, ampak jim ga daje državni proračun. Kazalnik stopnje finančne povezanosti občin z državnim proračunom za leto 2004 kaže, da le štiri slovenske občine niso prejele nič sredstev iz državnega proračuna (Markovci, Mengeš, Šempeter-Vrtojba, Trzin). Pod slovenskim povprečjem (16\%) je bilo le deset preučenih občin (Dol pri Ljubljani, Žirovnica, Komenda, Naklo, Borovnica, Hajdina, Starše, Horjul, Vodice, Divača), kar 32 občin pa je od države prejelo več kot $50 \%$ sredstev, največ občina Solčava s $86 \%$. Če bi se drobljenje občin še nadaljevalo, bi lahko prišlo do prevelikega pritiska na državni proračun, kar bi ogrozilo obstoj samih občin. Spremembe zakona o financiranju občin so napovedane za leto 2006 in naj bi občinam prinesle večjo finančno avtonomijo, pa tudi odgovornost za svoj razvoj (Čeh, 2006).

\section{REZULTATI RAZISKAVE}

\section{I Opremljenost občin z izbranimi storitvami in komunalno infrastrukturo}

Opremljenost $\mathrm{z}$ osnovnimi storitvenimi dejavnostmi in komunalno infrastrukturo je eden temeljnih pokazateljev stopnje razvoja določene lokalne skupnosti. Od nje je odvisna privlačnost okolja za bivanje in lokacijo gospodarskih dejavnosti (Perpar, 2002).

$\mathrm{V}$ anketnem vprašalniku smo spraševali po prisotnosti 17. storitev, ki so pomembne za vsakdanjo oskrbo in normalno življenje prebivalcev.

Osnovno šolo so imele vse občine, saj morajo po zakonu svojim prebivalcem zagotoviti osnovno izobraževanje. Poleg izobraževalne funkcije ima osnovna šola, zlasti v bolj odročnih predelih, med katere lahko upravičeno štejemo velik del anketiranih občin, tudi kulturno funkcijo. Šolski prostor je namreč pogosto zbirališče prebivalcev ob praznikih in prostor za različne kulturne, športne in zabavne prireditve. Sedem občin (Hodoš, Jezersko, Osilnica, Solčava, Tabor, Trnovska vas in Sv. Andraž v Slovenskih goricah) ni imelo matične osnovne šole, ampak podružnice oz. enote osnovnih šol iz sosednjih občin. Vrtec je bil prisoten v 94. občinah, brez so bili v občinah Dobje, Hajdina, Osilnica, Podlehnik, Sveti Andraž v Slovenskih goricah in Žetale, v Trnovski vasi pa so vrtec ravno gradili. Knjižnica v sklopu šole je bila prisotna $\mathrm{v}$ vseh občinah, medtem ko so imeli splošno knjižnico v 71. občinah. Dvorano za kulturne prireditve je imelo 88, telovadnico in športno igrišče pa 90 občin. Čeprav so tako dvorana kot telovadnica in igrišče ponavadi v sklopu šole, ponujajo možnost športnih aktivnosti in rekreacije ter kulturnega udejstvovanja vsem občanom.

Zdravstvena ustanova je po mnenju prebivalcev in zakonodajalcev ena pomembnejših institucij, ki jih mora zagotoviti občina. Zdravstveni dom je bil le v eni občini (Radeče), zdravstvena postaja ali zasebna ambulanta splošne medicine pa $v$ 75. občinah. Težavo glede zdravstvene oskrbe $v$ številnih občinah je predstavljal delovni čas ambulant, saj so nekatere delovale le enkrat ali dvakrat tedensko. V dveh občinah (Muta in Kuzma) je bila zdravstvena ambulanta $\mathrm{v}$ času anketiranja $\mathrm{v}$ gradnji. Zdravstvene ustanove ni imelo še 13 občin (Tišina, 
Velika Polana, Tabor, Odranci, Hodoš, Dobje, Kobilje, Braslovče, Veržej, Solčava, Šalovci, Dornava, Sv. Andraž v Slovenskih goricah). Lekarna je bila v 52. občinah, občine Kostel, Žetale in Osilnica so imele priročno zalogo najosnovnejših zdravil.

Slika 2: Prisotnost izbranih storitev v preučenih občinah

Figure 2: Presence of selected services in studied municipalities

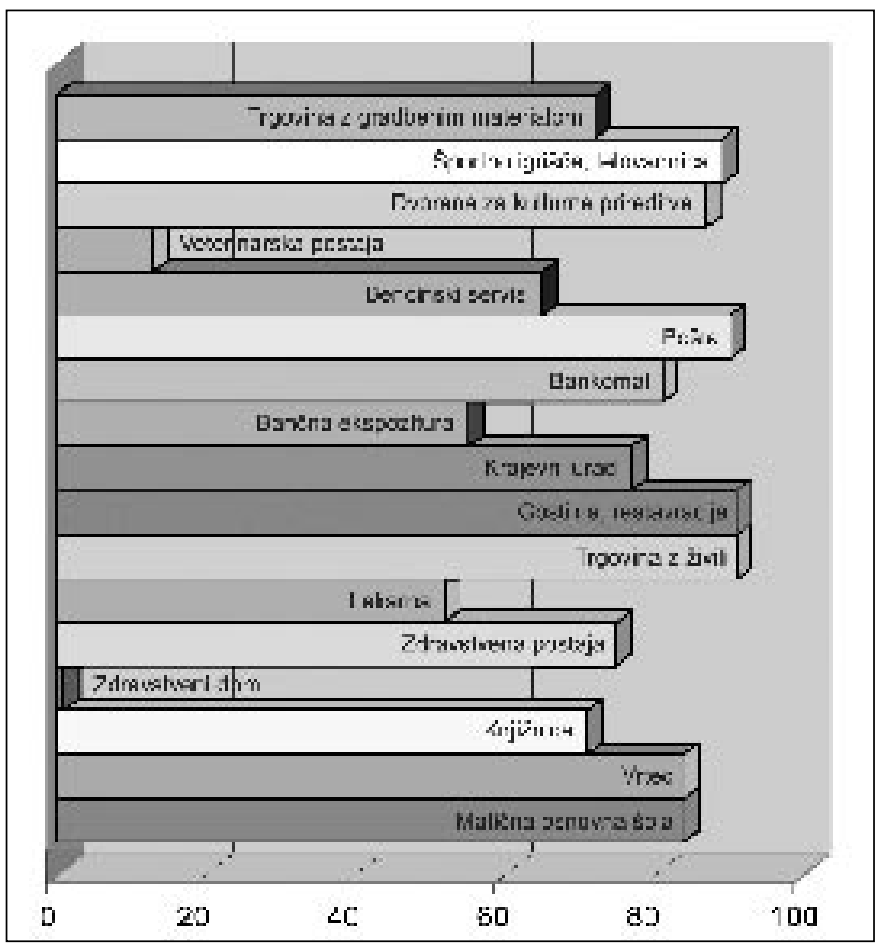

Vir: Anketa, 2005; Source: Questionnaire, 2005

Trgovino z živili in mešanim blagom ter gostinski objekt (gostilna, okrepčevalnica, bife) so po pričakovanju imele vse občine. Trgovino z gradbenim materialom je imelo 73 občin, največkrat v okviru kmetijske zadruge. Krajevni urad je bil v 78., medtem ko je bila pošta prisotna v vseh anketiranih občinah. Bankomat je imelo $90 \%$ občin, bančno ekspozituro pa 55 občin. Če upoštevamo Poštno banko Slovenije, je bila bančna poslovalnica prisotna v vseh anketiranih občinah. Bencinski servis je imelo 65, veterinarsko ambulanto pa le 13 občin.

Omenjene dejavnosti so večinoma skoncentrirane v občinskih središčih, kar je zaradi majhnosti občin razumljivo in pričakovano. Občinska središča morajo biti minimalno opremljena s storitvami za zadovoljitev zahtev in potreb prebivalcev v socialnem, kulturnem in gospodarskem pogledu. Opremljenost nekaterih naselij se je ravno zaradi pridobitve funkcije 
središča občine močno izboljšala, kar je vplivalo na izboljšanje kvalitete življenja v naselju samem in v okoliških naseljih. Nekatere občine so slabše opremljene in morajo probleme najosnovnejše oskrbe prebivalstva reševati v okviru medobčinskega sodelovanja.

Mnoge med anketiranimi občinami so se ob ustanovitvi soočile s pomanjkljivo ponudbo storitev. Zato smo vprašali, katere med prej navedenimi storitvami so nastale po ustanovitvi ali zaradi ustanovitve občine oziroma da bi zadostili v Zakonu o lokalni samoupravi predpisanim pogojem (popolna osnovna šola, primarno zdravstveno varstvo, komunalna opremljenost, poštne storitve, knjižnica, prostori za upravno dejavnost lokalnih skupnosti, z novelo zakona v letu 2005 sta bili črtani preskrba z življenjskimi potrebščinami in finančne storitve hranilnice ali banke).

V 35. občinah so postavili bankomate, v 15. so zgradili vrtec, v 14. lekarno, po deset občin je investiralo $\mathrm{v}$ gradnjo knjižnice ter športnega igrišča in telovadnice. $\mathrm{V}$ devetih občinah so bile zgrajene bančne ekspoziture in bencinski servisi, po osem občin pa je dobilo zdravstveno ambulanto, krajevni urad in dvorano za kulturne prireditve, šest pa veterinarsko ambulanto. Matična osnovna šola, pošta in gostinski objekt so bile nove pridobitve v desetih občinah, trgovina $\mathrm{z}$ živili in trgovina $\mathrm{z}$ gradbenim materialom pa $\mathrm{v}$ dveh. Ob navedenem je treba povedati, da so v četrtini občin pridobili tri in več storitev, od tega $\mathrm{v}$ desetih občinah več kot štiri storitve.

Da bi izboljšali ponudbo in predvsem olajšali dostop do nekaterih najpomembnejših storitev, so imeli v 36. občinah potujočo knjižnico, v 65. potujoče trgovine ter v 66. zdravniško pomoč na domu. Za prodajo živil (pekovski izdelki, zamrznjena živila, sadje in zelenjava) po občinskih naseljih izda občina posameznim prodajalcem dovoljenje. Zdravniška pomoč na domu (obiski zdravnikov in patronažnih sester) se izvaja v okviru osnovne zdravstvene dejavnosti, pomoč starejšim in bolnim občanom pri gospodinjskih opravilih in osebni negi pa preko centrov za socialno delo. Nekatere občine so sodelovale z domovi za upokojence, ki so ostarelim dostavljali hrano.

Z električno energijo so preskrbljene vse slovenske občine na celotnem svojem ozemlju, zato vprašanje o tovrstni infrastrukturi ni bilo postavljeno. Tudi s stacionarnimi telefonskimi priključki je bila preskrbljenost dobra, saj je imelo celotno pokritost 85 občin, delno pa šest (Rogatec, Bovec, Lovrenc na Pohorju, Kobarid, Benedikt, Kungota). Stacionarno telefonsko omrežje izgublja na pomenu zaradi izredno hitrega razvoja digitalnega mobilnega telefonskega omrežja, ki naj bi izboljšalo povezavo na območjih s skromnim omrežjem stacionarnih telefonov, to je v odmaknjenih območjih s samotnimi kmetijami, kjer je napeljava stacionarnega telefonskega omrežja predraga (Kladnik, 1997). Oskrba s pitno vodo ni bila zadovoljiva. Javno vodovodno omrežje so imela vsa naselja v 40. anketiranih občinah, v 51. občinah pa je bil na javni vodovod priključen le del prebivalstva. V nekaterih občinah je namreč še vedno veliko vaških in hišnih vodovodov. Ker ti vodovodi ne zadoščajo potrebam, poleg tega pa je kakovost vode velikokrat neustrezna, je cilj lokalnih skupnosti priključitev čim večjega dela prebivalstva v najkrajšem možnem času na javni vodovod. Zaradi razpršene poselitve in razgibanega reliefa je gradnja marsikje močno otežena in zahteva visoka finančna sredstva, zato je uresničevanje projektov oskrbe z vodo običajno dolgotrajno. Izračuni v nekaterih občinah so pokazali, da bi morale občine več let namenjati celotni proračun, da bi vsem prebivalcem zagotovile kvalitetno oskrbo s pitno vodo. To pa je zaradi številnih drugih 
potreb nemogoče, zato veliko finančnih sredstev prispevajo tudi prebivalci sami. Podobne težave so s kanalizacijskim omrežjem. Na celotnem območju občine je imelo kanalizacijo urejeno devet občin, 63 delno, pri čemer je največkrat mišljeno le občinsko središče, 19 občin pa javne kanalizacije še ni imelo. Čistilno napravo je imelo 57 občin. Vse občine, razen Mežice in Bistrice ob Sotli, so imele organiziran odvoz odpadkov iz vseh, omenjeni občini pa le iz lažje dostopnih naselij.

Opremljenost $\mathrm{s}$ kabelsko televizijo ne pomeni nujno potrebne infrastrukturne opremljenosti, kaže pa lahko na kakovost življenja v določeni lokalni skupnosti oziroma doseženo stopnjo razvoja, saj se za takšno investicijo navadno odločijo skupnosti, ki imajo osnovno infrastrukturo že urejeno (Perpar, 2002). Analiza rezultatov ankete je pokazala, da so imeli kabelsko televizijo po vseh naseljih v 19. občinah, v 30. je ni bilo, v 42. občinah pa je bila dostopna le delu prebivalstva.

Slika 3: Infrastruktura v preučenih občinah

Figure 3: Infrastructure in studiedmunicipalities

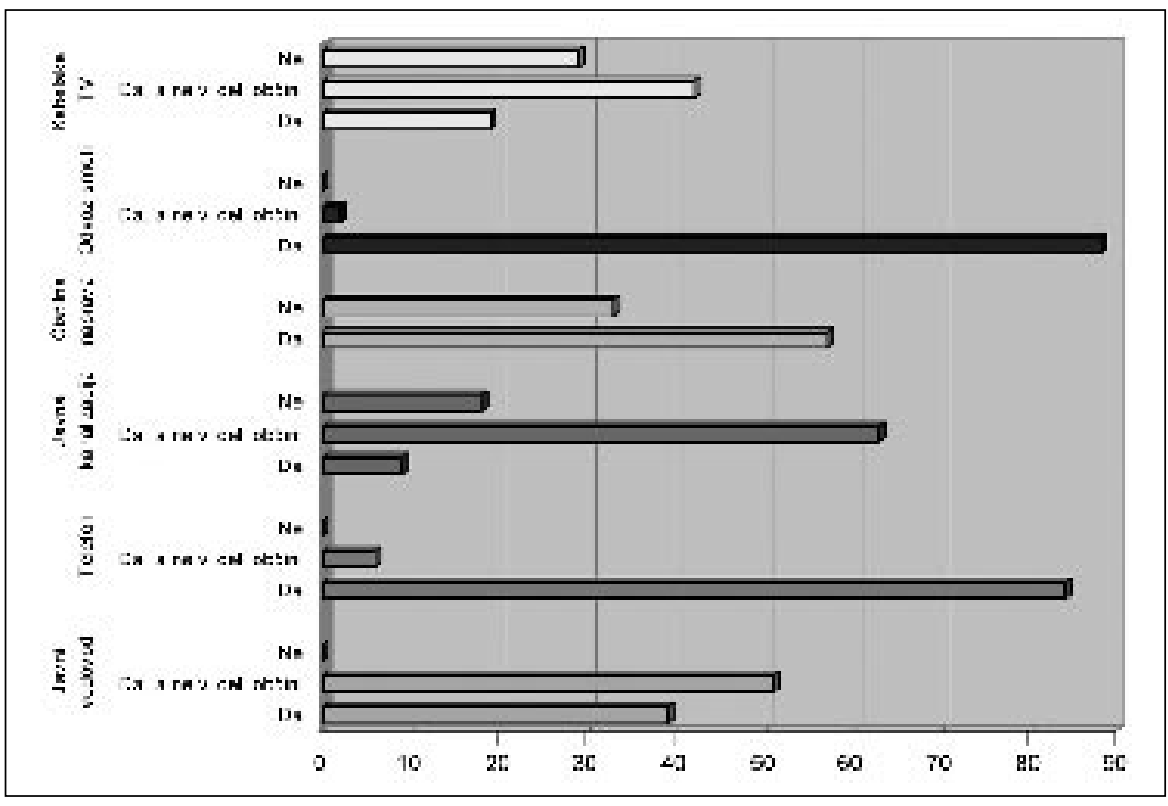

Vir: Anketa, 2005; Source: Questionnaire, 2005

\subsection{Razvojni potenciali in problemi ter prihodnji razvoj občin}

Razvojne možnosti posameznih občin, predvsem pa privlačnost območij za bivanje in razvoj različnih gospodarskih dejavnosti, so odvisne od naravnih in družbenih potencialov, s katerimi posamezna občina razpolaga. 
Slika 4: Razvojni potenciali v preučenih občinah

Figure 4: Developmental potentials in studied municipalities

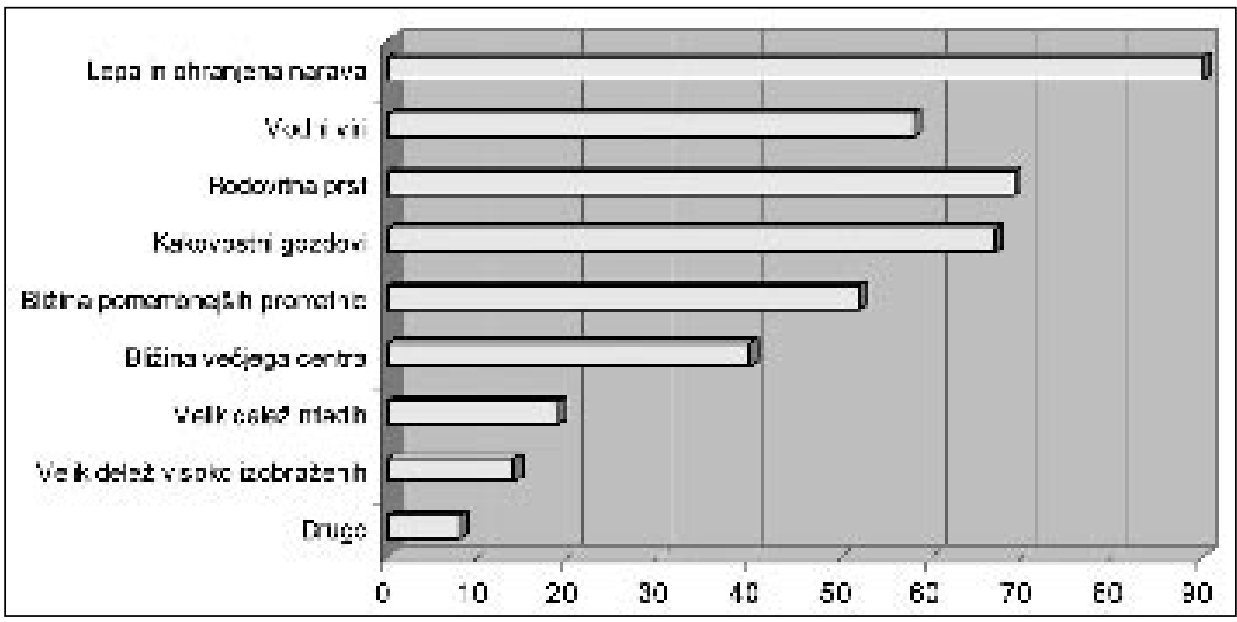

Vir: Anketa, 2005; Source: Questionnaire, 2005

Lepo in ohranjeno naravo so izpostavile prav vse občine. $Z$ bogatimi vodnimi viri (talna voda, termalni vrelci, izviri, reke) se je pohvalilo 58 , z rodovitno prstjo, kot enim od pogojev za razvoj kmetijstva, pa 70 občin. Kmetijske dejavnosti so imele v izbranih občinah še relativno velik pomen, kar je razumljivo, saj gre v veliki meri za odmaknjena podeželska območja s pomanjkanjem delovnih mest $\mathrm{v}$ drugih dejavnostih. Kakovostni gozdovi predstavljajo velik okoljski, rekreacijski in gospodarski potencial in so bili kot pomemben dejavnik prihodnjega razvoja izpostavljeni v 68. občinah. Bližina pomembnejših prometnic, ki pripomorejo k lažjemu migriranju na delo in boljši dostopnosti oskrbnih centrov, bo pomemben razvojni dejavnik v 52. občinah. V 40. občinah pa so menili, da bo pozitivno vplivala na razvoj občine bližina večjega centra, ki nudi vse pomembne storitve in delovna mesta tudi njihovim prebivalcem. Z velikim deležem mladega ali visoko izobraženega prebivalstva se je pohvalilo 19 oziroma 15 občin. Anketirani so navedli še nekatere potenciale, ki so bili uvrščeni v kategorijo »drugo«: delavnost, samooskrbna, bližina mejnega prehoda, bližina morja, kulturno-zgodovinske znamenitosti, aktivno prebivalstvo.

Pri razvojnih prizadevanjih se posamezne občine soočajo tudi z različnimi naravnimi in družbenimi ovirami. Med naravnimi ovirami razvoja so največ težav povzročale strmine, ki onemogočajo ali otežujejo kmetijsko dejavnost ter otežijo in močno podražijo gradnjo različnih objektov. Večje nadmorske višine in slabo rodovitno prst je kot razvojno oviro navedlo 21, ostrejše klimatske pogoje pa 20 občin. 
Slika 5: Razvojne ovire v preučenih občinah

Figure 5: Developmental problems in studied municipalities

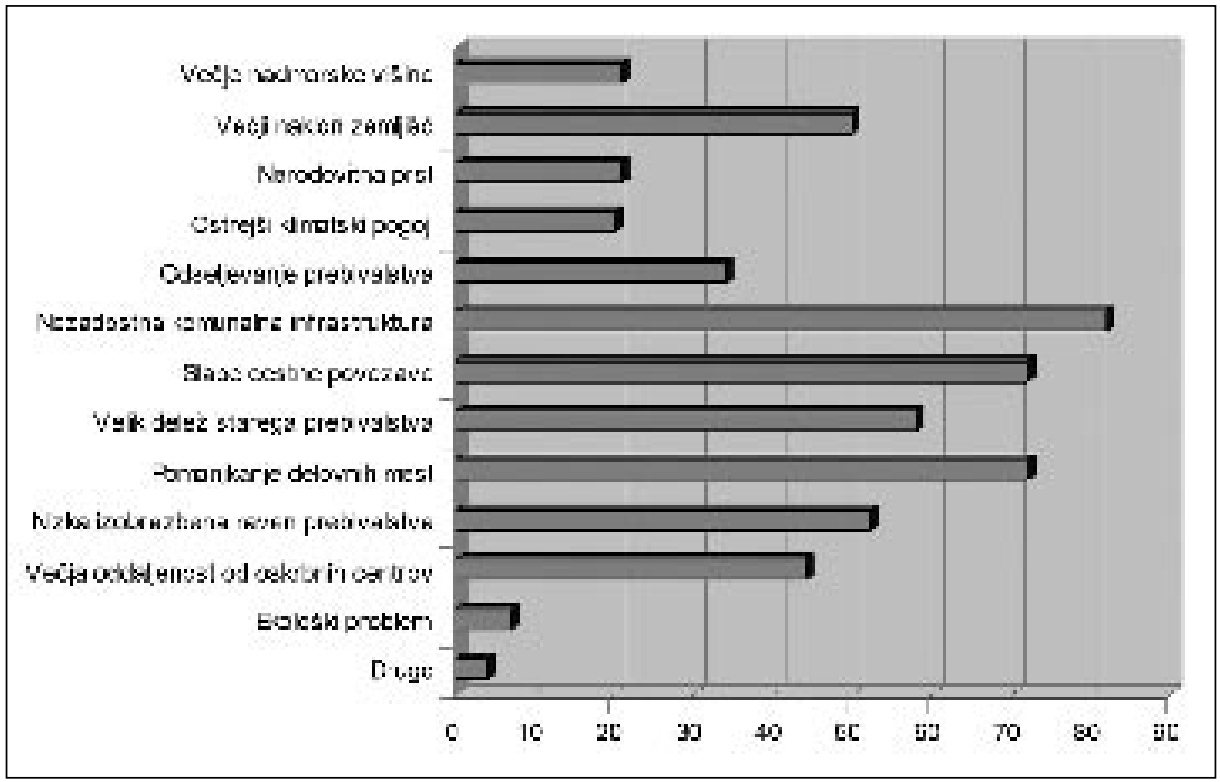

Vir: Anketa, 2005; Source: Questionnaire, 2005

Med družbenimi ovirami se je kot najpomembnejša ovira pokazala nezadostna infrastrukturna opremljenost, pri čemer sta, kot je bilo ugotovljeno, mišljeni predvsem vodovodno in kanalizacijsko omrežje. Z omenjeno težavo se je spopadalo 83 občin. Pomanjkanje delovnih mest in slabe cestne povezave, mišljena je zlasti kakovost lokalnih cest, so pomenile težavo v 73. občinah. Visoka brezposelnost - leta 2002 je kar 59 občin imelo stopnjo brezposelnosti nad državnim povprečjem - je bila po mnenju anketiranih posledica propadanja industrije. Velik delež starega prebivalstva je predstavljal oviro $\mathrm{v}$ 58., nizka izobrazbena raven prebivalstva pa v 52. občinah. Vrednost indeksa staranja pod demografskim pragom je imelo le 13 občin, v vseh ostalih naj bi bila naravna reprodukcija prebivalstva že onemogočena. Kar 40 občin je imelo vrednost indeksa staranja nad 100, kar pomeni, da je delež starega prebivalstva že presegel delež mladega. Podatki kažejo, da se bo večina preučenih občin $v$ prihodnosti soočila $\mathrm{z}$ nadaljnjim zmanjševanjem števila prebivalstva in njegovim staranjem. Izobrazbena sestava je bila kljub očitnim pozitivnim spremembam še vedno precej pod slovenskim povprečjem. Nad slovenskim povprečjem je bil delež oseb brez izobrazbe in z nedokončano osnovno šolo, medtem ko je bil delež oseb s srednjo in višjo ter visoko izobrazbo pod slovenskim povprečjem. Slabi izobrazbena in starostna sestava prebivalstva predstavljata pomembni strukturni oviri za hitrejši, sodobnejši in inovativnejši razvoj, česar so se zavedali tudi predstavniki občin. Čeprav so se vsi strinjali, da je potrebno posvetiti posebno pozornost aktivnostim mladih in izobraževanju prebivalstva, teh ciljev niso 
uresničevali v potrebni meri. $Z$ večjo oddaljenostjo od oskrbnih centrov je bilo zaznamovanih 45 občin, odseljevanje prebivalstva pa je pomenilo težavo v 35. občinah. Statistični podatki so pokazali, da se je število prebivalcev med letoma 1991 in 2002 povečalo v 28. občinah, predvsem zaradi priseljevanja prebivalstva iz drugih občin, zmanjšalo $v 30$. in ostalo na isti ravni v 33. občinah. Prostorska razporeditev občin z zmanjševanjem števila prebivalstva kaže, da gre za odmaknjene občine oziroma za območja, kjer je depopulacija prisotna že več desetletij, medtem ko občine s prirastom števila prebivalstva ležijo v okolici Ljubljane in na Gorenjskem, torej na območjih s tradicionalno rastjo števila prebivalstva.

Z ekološkimi (okoljskimi) problemi, ki so posledica preteklega vlaganja $\mathrm{v}$ okoljsko obremenjujočo industrijo, so se soočali v sedmih občinah. Brez okoljskih problemov so bili v občinah Vodice, Naklo, Horjul, Cerkvenjak, Braslovče in Komenda.

Posamezne občine imajo glede na naravne danosti, razpoložljive človeške vire ter tradicije iz preteklosti različne možnosti razvoja. Ker se v zadnjem desetletju vse bolj izpostavlja endogeni razvoj, ki naj bi temeljil na lastnih naravnih in družbenih potencialih območja, je pomembno, da se občina zaveda svojih potencialov in ovir.

\section{Slika 6: Področja z neizkoriščenimi razvojnimi potenciali}

Figure 6: Economic spheres with unexploited developmental potentials

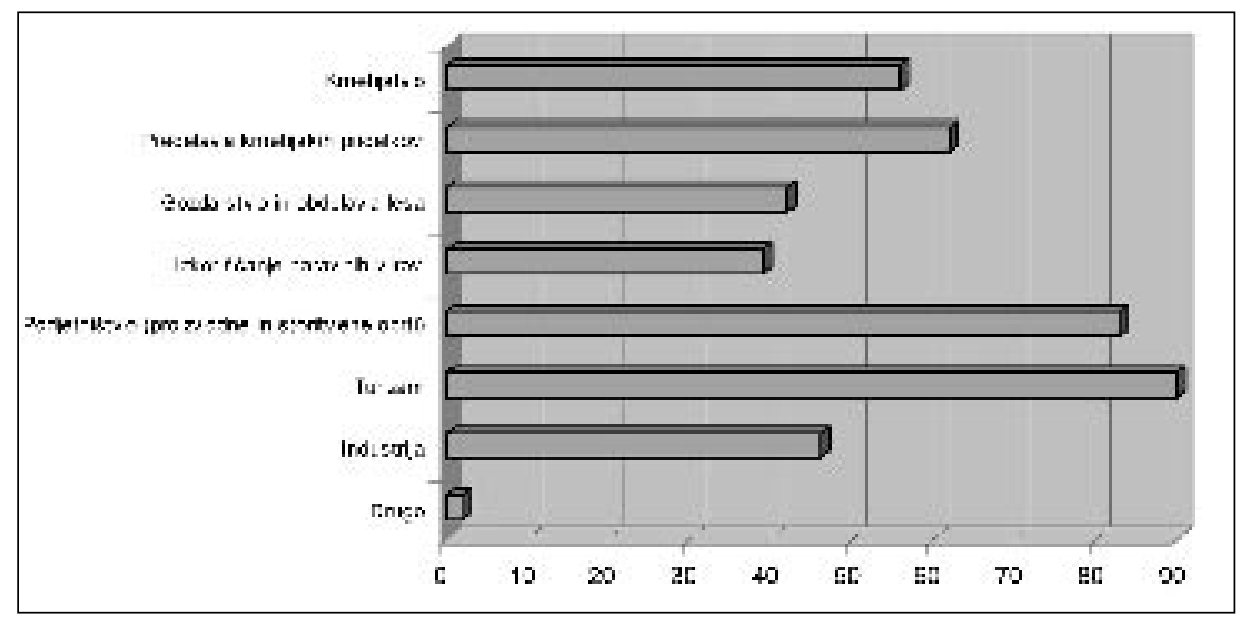

Vir: Anketa, 2005; Source: Questionnaire, 2005

Po ocenah anketirancev so imele občine še največ razvojnih možnosti v turizmu (90 občin), sledi pospeševanje in razvoj podjetništva ( 83 občin). Na področju razvoja kmetijstva so videli neizkoriščene potenciale v 56. občinah, v predelavi kmetijskih pridelkov pa v 62 . občinah. Gozdarstvo in obdelava lesa bi se lahko bolje razvila v 42., izkoriščanje naravnih virov v 39., industrija pa v 46. občinah. Občina Dobrovnik je navedla, da ima možnosti v razvoju informatike; v omenjeni občini namreč poteka razvojni projekt »e-vas«. 
Izvajanje razvojnih aktivnosti je odraz dinamičnosti posameznih območij ter želje po napredku in izboljšanju bivanjskih in delovnih pogojev prebivalcev. Različne razvojne aktivnosti so v času anketiranja potekale prav v vseh občinah. Med izvajajočimi se razvojnimi aktivnostmi je prevladovala izgradnja ali obnova infrastrukture: v 47. občinah so obnavljali ali gradili vodovodno omrežje, v 71. kanalizacijsko omrežje, v 18. pa čistilno napravo. Med aktivnostmi v okviru programa CRPOV, ki je potekal v 29. občinah, so bili predvsem projekti ureditve in obnove vasi, ohranjanje in oživljanje kulturne dediščine ter organiziranje turistične ponudbe. V 12. občinah so gradili obrtno cono, s čimer naj bi pospešili razvoj podjetništva in s tem povečali gospodarsko razvitost občine. V petih občinah je potekala povečava osnovne šole, $v$ enakem številu občin so adaptirali vrtce, $v$ štirih občinah so gradili telovadnico oziroma športno dvorano, v dveh pa knjižnico. Asfaltiranje in posodobitev cestnega omrežja je potekala v 14. občinah. Ostale aktivnosti so bile še: gradnja doma za ostarele, zdravstvene ambulante, plinovoda, javne razsvetljave, bencinskega servisa in stanovanj.

Del finančnih sredstev za omenjene aktivnosti so občine dobile tudi iz evropskih strukturnih skladov, največ v okviru programov SAPARD in PHARE (izgradnja komunalne infrastrukture) ter PHARE CBC in INTERREG (projekti čezmejnega sodelovanja in razvoja podeželja).

Pri finančno in izvedbeno zahtevnejših projektih je bilo vidno povezovanje občin. Medobčinsko sodelovanje je vključevalo sosednje občine in se je nanašalo le na posamezna vprašanja, običajno na področju komunalne infrastrukture in komunalnih storitev, ki gredo preko meja občin, pa tudi na področju pospeševanja gospodarstva in dejavnosti javnih služb lokalnega pomena. Le pet občin je odgovorilo, da ne sodelujejo z drugimi občinami. Za skupno gradnjo vodovoda so se odločili v 24. občinah, kanalizacije v sedmih in cest v devetih občinah. Skupno so reševale probleme odlaganja komunalnih odpadkov in druge ekološke probleme ter ustanavljale skupne javne zavode, npr. knjižnice, lekarne in medobčinske inšpekcijske službe. Občine so se povezovale tudi pri pripravi programov razvoja turizma. Kar 17 občin pa se je pohvalilo, da sodelujejo z občinami preko meje v okviru programov Evropske unije PHARE CBC in INTERREG. V dveh občinah so se odločili, da bodo s sosednjimi občinami zgradili obrtno cono.

Poleg aktivnosti, ki so jih izvajali v občinah v času anketiranja, nas je zanimalo tudi, katere aktivnosti so $\mathrm{v}$ občinah izvajali $\mathrm{v}$ letih od nastanka občine, za katere so porabili največ proračunskih sredstev in katere med naštetimi aktivnostmi bodo imele prednost $\mathrm{v}$ naslednjih petih letih. Po pričakovanju so v večini občin izvajali različne razvojne aktivnosti, v največjem številu občin pa so prevladovala vlaganja $\mathrm{v}$ izgradnjo ali posodobitev komunalne infrastrukture in cest ter različne oblike pomoči ostarelim občanom. Veliko občin je vlagalo tudi v oživitev kulturne dejavnosti, razvoj turizma, pomoč kmetijam pri posodabljanju in uvajanju dopolnilnih dejavnosti. Spodbujanje kulture na podeželju je potekalo z izgradnjo objektov, ki omogočajo izvajanje različnih kulturnih dejavnosti (npr. dvorane za kulturne prireditve). V občinah so podpirali tudi različne neformalne oblike izobraževanja prebivalstva, na primer z organizacijo različnih delavnic, predavanj in tečajev (računalništvo, zdrava prehrana) ter z izgradnjo knjižnic. V številnih občinah so se zavedali, da je potrebno posebno pozornost nameniti mladini in jim pomagati pri organizaciji kulturnih in športnih prireditev, saj naj bi s tem delno zadovoljili njihove potrebe in jim pokazali, da je tudi na podeželju dovolj aktivnosti 
za mlade. To naj bi vsaj malo pomagalo k njihovi odločitvi, da bi tudi v prihodnje ostali v domači občini. Delno naj bi k temu prispevale tudi aktivnosti v zvezi z ohranjanjem delovnih mest in ustvarjanjem novih, tudi s pomočjo pri ustanavljanju lastnih podjetij.

Slika 7: Razvojne aktivnosti v preučenih občinah v času od njihovega nastanka do leta 2005 Figure 7: Developmental activities in studied municipalities since their establishment till 2005

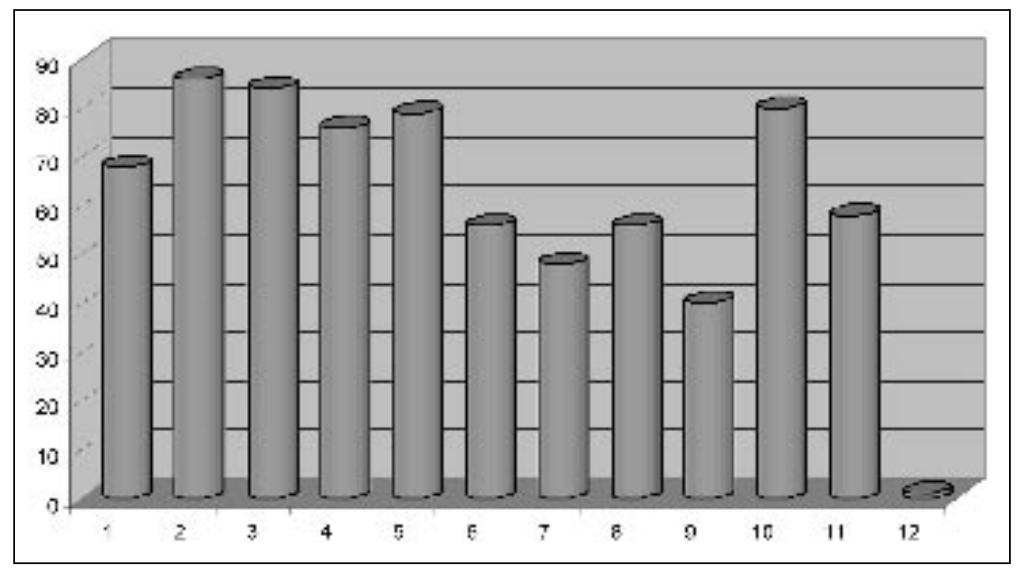

Vir: Anketa, 2005; Source: Questionnaire, 2005

Preglednica 1: Razvojne aktivnosti v preučenih občinah v času od njihovega nastanka do leta 2005 Table 1: Developmental activities in studied municipalities since their establishment till 2005

\begin{tabular}{|l|l|c|c|}
\hline 1. & $\begin{array}{l}\text { Pomoč kmetijam pri različnih investicijah (posodabljanje kmetij, } \\
\text { uvajanje dopolnilnih dejavnosti) }\end{array}$ & 68 & $74,4 \%$ \\
\hline 2. & $\begin{array}{l}\text { Gradnja ali posodobitev komunalne infrastrukture (vodovod, } \\
\text { kanalizacija, telefon) }\end{array}$ & 86 & $94,5 \%$ \\
\hline 3. & Gradnja ali posodobitev cestnega omrežja & 84 & $92,3 \%$ \\
\hline 4. & Razvoj turizma & 76 & $83,5 \%$ \\
\hline 5. & Oživitev kulturne dejavnosti & 79 & $86,8 \%$ \\
\hline 6. & Izobraževanje prebivalstva & 56 & $61,5 \%$ \\
\hline 7. & Ohranjanje, oživitev domačih obrti & 48 & $52,7 \%$ \\
\hline 8. & Ohranjanje delovnih mest in ustvarjanje novih & 56 & $61,5 \%$ \\
\hline 9. & Pomoč pri ustanavljanju podjetij & 40 & $43,9 \%$ \\
\hline 10. & Pomoč ostarelim občanom & 80 & $87,9 \%$ \\
\hline 11. & Posebne aktivnosti za mlade & 58 & $63,7 \%$ \\
\hline 12. & Drugo: & 1 & $1,0 \%$ \\
\hline
\end{tabular}

Vir: Anketa, 2005; Source: Questionnaire, 2005 
V prihodnjih petih letih bodo občine izvajale več različnih aktivnosti, prednostne pa bodo: gradnja in posodobitve komunalne infrastrukture (58 občin), razvoj turizma (25 občin), pomoč kmetijam pri posodabljanju in uvajanju dopolnilnih dejavnosti (4 občine), izobraževanje prebivalstva in ohranjanje delovnih mest (po dve občini).

Izjemno velika vlaganja $\mathrm{v}$ nekatere razvojne projekte so številne občine prisilile $\mathrm{v}$ najem posojil. Leta 2005 je bila približno četrtina slovenskih občin zadolženih bolj kot je to dovoljeval zakon (10 \% letnih prihodkov). Istega leta je državni zbor dvignil zgornjo mejo zadolževanja občin na $20 \%$, izjemoma tudi več (Poglajen, 2005).

Na koncu so anketiranci podali oceno o koristnosti nastanka občin in njihovem prihodnjem razvoju. Kar 90 predstavnikov občin je bilo prepričanih, da je ustanovitev občine pozitivno vplivala na razvoj območja in da se prebivalcem godi bolje, odkar imajo občino. Napredek je viden prav na vseh področjih, razlogi pa so naslednji:

1. Pred ustanovitvijo današnjih občin se je investiralo le v občinsko središče, medtem ko so bili obrobni deli nekdaj velikih občin razvojno zapostavljeni. Zaradi nastanka novih občin ravno na teh območjih so se življenjske razmere izboljšale in se še izboljšujejo.

2. Nastanek občine je prinesel več finančnih sredstev, ki omogočajo izvajanje različnih razvojnih aktivnosti. Predvsem je opazen velik napredek na področju obveznih javnih služb (šolstvo, zdravstvo) in urejanja komunalne infrastrukture. Finančna sredstva se usmerjajo bolj racionalno, glede na potrebe občin. Občine se neodvisne in samostojne pri odločanju, katerim projektom in razvojnim aktivnostim bodo dale prednost pri realizaciji. Kljub povečanim finančnim sredstvom, pa jih še vedno ni dovolj za uresničitev in zadovoljitev vseh potreb, zato so se občine prisiljene prekomerno zadolževati.

3. Politika se je približala ljudem in njihovim potrebam. Majhna občina namreč pozna potrebe in probleme svojih prebivalcev, zato jih lahko hitro in učinkovito rešuje. Poleg tega pri odpravljanju težav in pri razvojnih projektih sodelujejo tudi občani s svojimi predlogi; vključeni so v odločanje o lastnemu razvoju, kar jim daje občutek pomembnosti in družbene koristnosti. Prebivalci občin se večinoma zavedajo, da je razvoj odvisen od njih samih, da temelji na njihovih sposobnostih in inovativnosti.

Oziroma kot je rekel predstavnik občine Šalovci: »Ker si svojo prihodnost gradimo sami«.

4. Nastanek občin je povzročil decentralizacijo, nekateri predeli so se šele takrat začeli razvijati in so postali prepoznavni v okviru Slovenije, pa tudi širše. Le v občini Cankova so mislili drugače, vendar, žal, obrazložitve niso podali.

Optimistično gledanje na prihodnji razvoj je bilo moč zaznati tudi v demografsko ogroženih in gospodarsko manj razvitih občinah, kar kaže na željo in odločenost vodstvenih ljudi, da se ta območja v prihodnje ohranijo poseljena in gospodarsko aktivna, kar je predpogoj za nadaljnje razvojne aktivnosti. Le osem občin (Cankova, Turnišče, Radeče, Rogašovci, Muta, Žužemberk, Bistrica ob Sotli, Loški Potok) jih je ocenilo, da v prihodnje ne pričakujejo večjih sprememb.

Nared (2002) je z izbranimi kazalci gospodarske strukture in trga delovne sile ter naselbinske in prebivalstvene sestave določil razvitost slovenskih občin v letu 2002. Na osnovi 
vrednotenja vrednosti izbranih kazalcev je slovenske občine razvrstil $v$ šest razredov:

- ekstremno nadpovprečno razvita občine (1 občina),

- močno nadpovprečno razvite občine (13 občin),

- nadpovprečno razvite občine (31 občin),

- podpovprečno razvite občine (76 občin),

- močno podpovprečno razvite občine (56 občin),

- ekstremno podpovprečno razvite občine (15 občin).

Med $\mathrm{v}$ raziskavo vključenimi občinami se je $\mathrm{v}$ skupino močno nadpovprečno razvitih občin uvrstila občina Naklo, v skupino nadpovprečno razvitih občine Brezovica, Žiri, Horjul, Preddvor, Komenda, Vodice, Dol pri Ljubljani in Šmartno ob Paki. Vse ostale občine so se uvrstile med podpovprečno razvite: 27 med podpovprečno razvite, 41 med močno podpovprečno razvite in 14 med ekstremno podpovprečno razvite občine.

\section{SKLEP}

V letu 2006 se je 193 občinam pridružilo še 17 novih občin. Repovž (2002) razlaga, da se želja prebivalcev po občini veča z zaostalostjo območja. Gospodarsko šibka območja ne morejo zadovoljiti potreb prebivalcev, zato je najboljša možnost za pridobitev dodatnih sredstev in vzpodbujanje razvoja ustanovitev občine. Velika pomanjkljivost majhnih občin je po mnenju Repovža (2002), da se velik del denarja porabi za delovanje občine in ne za razvojne projekte. Druga slabost je, da drobljenje na majhne občine povzroča centralizacijo države, saj se vse pomembnejše pristojnosti postopno prenašajo na državo. Boj proti centralizaciji pomenijo namreč močne občine, ne pa šibke, popolnoma odvisne od države. V takšni situaciji se pokaže potreba po povezovanju občin in ustanovitvi srednje ravni (samo)uprave oziroma pokrajin.

Mnogo občin se je ob svojem nastanku soočilo $\mathrm{z}$ velikim razvojnim zaostankom na vseh področjih, zato so začele pospešeno izvajati številne projekte za izboljšanje življenja prebivalcev (posodabljanje ali izgradnja vodovodnega, kanalizacijskega in cestnega omrežja, plinifikacija, postavljanje ekoloških otokov za ločeno zbiranje odpadkov in sanacija divjih odlagališč, izgradnja in posodobitev objektov za osnovnošolsko izobraževanje in predšolsko vzgojo, zdravstvenih ambulant in bančnih podružnic, gradnja obrtnih con in parkirišč), s katerimi naj bi pokazale svoj prispevek k razvoju območij.

Občine še desetletje po ustanovitvi popravljajo napake iz preteklosti; ustvarjajo pogoje za življenje prebivalstva in pripravljajo temelje za gospodarski razvoj, ki naj bi v večini občin slonel na razvoju podjetništva in turizma. Kljub nasprotovanju ustanavljanju majhnih občin so se pokazali, pa čeprav na račun državnega proračuna, pozitivni rezultati, ki upravičujejo njihov nastanek. Pozitivni učinki nastanka občin se kažejo predvsem v opremljenosti občinskih središč s storitvami in v izgradnji komunalne infrastrukture. Omenjena infrastruktura določa privlačnost območja za bivanje in delo ter možnosti prihodnjega gospodarskega razvoja. Zato ni presenečenje, da si je veliko občin kot prednostno nalogo zadalo urejanje infrastrukture, v katero vlagajo velik del občinskih proračunov. Čeprav je bilo na tem področju strojenega 
veliko, so zaostanki tolikšni, da jih bo kratkoročno težko nadoknaditi. Čeprav lahko z izgradnjo in posodabljanjem infrastrukture bistveno izboljšamo življenjske pogoje in omilimo vsakdanje stiske podeželskega prebivalstva, pa to ne pomeni »pravega razvoja«, ker se zelo malo vlaga v izboljšanje gospodarske sestave in v izobraževanje prebivalstva. Kljub temu je izboljšanje infrastrukture prvi korak na poti k izboljšanju razmer in prva stopnja razvoja območja. Šele ko bodo občine uspele odpraviti posledice preteklega (ne)razvoja se bodo lahko premaknile naprej in posvečale razvoju drugih dejavnosti.

Čeprav postavlja zakon za ustanovitev občin več pogojev, so jih nekatere občine izpolnile šele po nastanku, nekatere pa še vedno ne. Na nek način je to razumljivo, saj so občine majhne in bi bilo neekonomično, da bi imela vsaka npr. zdravstveni dom, lekarno ali veterinarsko postajo. Zato slabše opremljene občine rešujejo probleme oskrbe prebivalstva $\mathrm{v}$ okviru medobčinskega sodelovanja. Na območjih z več majhnimi občinami brez izrazitega središča (npr. predeli v vzhodni Sloveniji) bi bilo potrebno izbrati središča z najprimernejšo lego in jih bolje opremiti. Opremljenost (zdravstvena ambulanta, lekarna, bančna podružnica, različne storitve) nekaterih občinskih središč se je ravno zaradi pridobitve upravne funkcije močno izboljšala, kar je vplivalo na izboljšanje oskrbe in kakovosti življenja v naselju samem in v okolici. Nastanek vseh dejavnosti je prispeval tudi k povečanju števila in pestrosti ponudbe delovnih mest. Ob nastanku občin se je pojavilo določeno število delovnih mest tudi v javni upravi, saj so občine za svoje delovanje morale zaposliti nekaj ljudi. Delež zaposlenih v storitvah se je zaradi vseh omenjenih dejavnosti najbolj povečal v majhnih občinah z majhnim deležem delovno aktivnega prebivalstva. $S$ tem se je povečala zaposlenost višje in visoko izobraženih in preprečila odselitev ali vsaj socialna stiska določenega števila ljudi zaradi brezposelnosti.

Bodoči razvoj občin je pogojen z značilnostmi prebivalstva in gospodarstva, s stanjem infrastrukture in naravnimi danostmi ter deloma z opredelitvijo razvojnih ciljev, še najbolj pa je odvisen od spodbud in sposobnosti ljudi, ki tam živijo. Po mnenju anketirancev tako občinski upravi kot občanom volje ne manjka, iz česar izhaja tudi prepričanje, da se bo napredek občin kazal tudi v prihodnje. Prizadevanja občin za izboljšanje stanja in optimističen pristop $\mathrm{k}$ prihodnjemu razvoju, bodo pozitivne rezultate še pomnožili. Naivno pa bi bilo pričakovati, da bodo občine same rešile težave le na osnovi lastnih potencialov in kapitala, saj nobenega nimajo dovolj. Majhne občine so in bodo odvisne od državnih in drugih pomoči. Zaradi tega in načel trajnostnega ter endogenega razvoja je potrebno spodbujati oblikovanje občin, ki bi bile čim manj odvisne od državnega proračuna in čim bolj razvojno samoiniciativne. Nujno potrebno bo intenzivnejše povezovanje občin, ker bodo s skupnimi močmi lažje uresničevale razvojne projekte in konkurirale na trgu.

\section{Literatura}

Čeh, S., 2006. Od odgovornih občin do odgovornih pokrajin. Delo (25. januar 2006), str. 15. Čokert, A., 2005. Teritorialni del reforme lokalne samouprave v Sloveniji. V: Regionalno planiranje in regionalni razvoj med teorijo in prakso. Ljubljana, Filozofska fakulteta, Oddelek za geografijo. (Dela, 24, str. 207-217) 
Demšar, M., 2004. Delovanje občin na področju prostorskega planiranja in komunalnega gospodarstva. V: Prostorske znanosti za 21. stoletje. Ljubljana, Fakulteta za gradbeništvo in geodezijo, str.203-209.

Finančni kazalniki občin za leto 2004. URL: http://www.fu.uni-lj.si/sib/podatki\%sib202004/ globalni htm (citirano 16. 9. 2005)

Katalog regionalnih delitev Republike Slovenije 2001. 2001. Ljubljana, Statistični urad Republike Slovenije, 168 str.

Kladnik, D., 1997. Nekateri prostorski vidiki telefonskega omrežja v Sloveniji. Geografski vestnik, 69, str. 139-160.

Nared, J., 2002. Razvitost slovenskih občin in nadaljnje razvojne perspektive. Geografski vestnik, 74, 2, str. 33-46.

Pečar, J., 2002. Regionalni vidiki razvoja Slovenije (in poslovanje gospodarskih družb v letu 2001. Ljubljana, Urad za makroekonomske analize in razvoj. (Delovni zvezek, 7, 76 str.)

Pečauer, M., 2006. Priložnost ali potrata. Delo (10. april 2006), str. 1.

Perpar, A., 2002. Razvojne značilnosti slovenskega podeželja: magistrsko delo. Ljubljana, Biotehniška fakulteta, Oddelek za agronomijo, 205 str.

Poglajen, J., 2005. Občine v dolgovih do vratu. Delo. (29. september 2005), str. 2.

Popis prebivalstva 1991, tabele agregiranih podatkov na nivoju današnjih občin za prebivalstvo po spolu in aktivnosti (brez oseb, ki delajo v tujini in družinskih članov, ki z njimi živijo v tujini), po spolu in starosti, prebivalstvo, staro 15 in več let, po spolu, šolski izobrazbi in pismenosti, aktivno prebivalstvo, ki opravlja poklic, po dejavnosti (brez oseb, ki delajo v tujini in družinskih članov, ki z njimi živijo v tujini). 2005. Ljubljana, Statistični urad Republike Slovenije. (računalniški izpis)

Repovž, G., 2002. Ko ima prav še Pavle Rupar. Delo. Sobotna priloga. (23. februar 2002), str. 1.

Statistične informacije, prebivalstvo - popis prebivalstva, gospodinjstev in stanovanj-rezultati po občinah. 2003. Ljubljana, Statistični urad Republike Slovenije, 73 str.

Taškar, J. 2006. Dobili naj bi še 13 novih občin. Delo (30. januar 2006), str. 1.

Taškar, J., 2006a. Slovenija bo imela po novem vsaj 210 občin. Delo (10. april 2006), str. 1.

Zakon o lokalni samoupravi. Uradni list RS 72/1993, 72/2005.

Zakon o spodbujanju skladnega regionalnega razvoja. Uradni list RS 93/2005.

Zakon o spremembah in dopolnitvah zakona o financiranju občin. Uradni list RS 90/2005.

Zakon o ustanovitvi občin in o določitvi njihovih območij. Uradni list RS 69/1994, 75/1998, $52 / 2002,27 / 2006$.

\section{THE ROLE OF SMALL MUNICIPALITIES IN DEVELOPMENT OF RURAL AREAS IN SLOVENIA}

\section{Summary}

Although Slovenia already has 193 municipalities, in 200717 new municipalities will come to life, emerging through the referendums in January and April 2006. It seems that the 
process of establishing new municipalities has not been concluded yet.

The research included 91 (out of 95) municipalities, which had in 2005 less than 5000 inhabitants, which is the legally prescribed threshold for the establishment of a municipality. The purpose of the research was, by means of analysing the available statistical and survey data, to:

- $\quad$ record the existing provision of municipalities with services and public utility infrastructure,

- determine the situation in the local communities and the development processes underway in them,

- $\quad$ determine the key problems of local communities, their needs and development possibilities, and

- $\quad$ assess the efficiency of local self-government in Slovenia.

On their establishment, many municipalities studied faced large development setbacks in all areas, therefore, they started to intensively implement many projects in order to improve the life of their inhabitants (modernisation or construction of water distribution, sewage and road networks, introduction of gas pipeline network, setting up of ecological islands for separate collection of waste, and remediation of illegal waste dumps, construction and modernisation of the facilities for primary and pre-school education, out-patient clinics and bank branches, construction of small-business areas and parking lots), with which they meant to show that their existence was justified. In the opinion of the respondents, positive effects of the establishment of the municipalities have showed in all areas of life. The discussions and data analysis indicate that this mostly involves improvements in the provision of municipality centres with services and the construction of public utility infrastructure. The latter shows the level to which a local community is developed, determines the attractiveness of an area to live and work in, and its chances of future economic development. Unfortunately, on their emergence certain municipalities faced extremely poor public utility infrastructure. Therefore, it is no wonder that many municipalities set themselves the priority to organise the infrastructure. In as many as 86 municipalities, most investments were dedicated to the construction of a water distribution or sewage network, and 84 municipalities primarily invested in the construction and renovation of their roads. Although much has been done in this area, their lagging behind is so large that it will be difficult to compensate for on the short run. People are very satisfied with what has been achieved, although it does not mean "true development", as very little is invested in the improvement of the economic composition and education of the inhabitants. If the municipalities were still part of the large former municipalities, which allocated most of their funds to the development of municipality centres, not even the changes mentioned above would have happened. Only when the municipalities manage to eliminate the consequences of the past (non-)development will they be able to move on and focus on the development of other activities. The improvement of the public utility infrastructure is the first step on the way to improving the conditions and the first stage in the development of an area.

Although the legislation prescribes several conditions for the establishment of a municipality, some of the municipalities only met them after they had been founded, and some have not met them yet. In a way, this is understandable, as some municipalities are 
very small and it would also be uneconomical for them to each have their own outpatient clinic, pharmacy or bank branch. Consequently, poorly equipped municipalities resolve their problems concerning the supply to the inhabitants within inter-municipal cooperation. Their new function as a municipality centre was the very reason why the equipment improved considerably, which enhanced the supply and the quality of life in these settlements themselves and in the surrounding settlements.

The results of the survey show that the municipalities are well aware of their problems and development possibilities. Among social obstacles, insufficient infrastructure turned out to be the most important hindrance ( 83 municipalities). Lack of jobs and high unemployment as well as poor quality of local roads appear in 73 municipalities. Large share of elderly inhabitants is an obstacle in 58 municipalities, and low education level of people hinders 52 of them. Large distance from supply centres characterises 45 municipalities, and 35 municipalities face emigration of their inhabitants. Almost all municipalities have financial problems, therefore, they also respond to invitations to tender to obtain money from the European structural funds. The respondents saw the most development possibilities in the development of tourism (90 municipalities), followed by the promotion and development of entrepreneurship (83 municipalities). In the field of agricultural development, they see unexploited potentials in 56 municipalities, while 62 of them find them in the processing of agricultural products. Forestry and wood processing could develop further in 42 municipalities. Most of the municipalities investigated do not have sufficient development capacities of their own, which results in inter-municipal cooperation. The latter is primarily evident in projects demanding in terms of finance and implementation. Only 5 municipalities answered that they do not cooperate with the neighbouring municipalities. Most frequently, inter-municipal cooperation exists in the construction of public utility infrastructure. Twenty-four municipalities decided to jointly construct their water distribution networks, seven their sewage networks and nine municipalities their roads. Municipalities also link in the preparation of their development programmes, primarily tourism development programmes. They also jointly resolve the problems concerning the disposal of municipal waste and other ecological issues, and found common public institutes, such as libraries, pharmacies and inter-municipal inspection services. As many as 17 municipalities said that they cooperate with municipalities across the border within the European Union programmes PHARE CBC and INTERREG.

All respondents but one assessed that the establishment of the municipality had a positive effect on the development of the area. Regarding future development, 8 assessed that they did not expect major changes, while all other were convinced that the municipality would develop. It was also possible to notice an optimistic view of the future development in the demographically endangered and economically less developed municipalities, which shows the desire and decidedness of the leaders to also maintain these areas settled and economically active in the future.

The future development of municipalities depends on the characteristics of the inhabitants and the economy, the state of infrastructure and natural conditions, and partly the definition of development goals, and most of all it depends on the stimulations and abilities of the people who live there. According to the respondents, both the municipal administrations and people do not lack the will, which also results in the conviction that municipalities will also develop 
in the future. However, it would be naive to expect the municipalities to resolve their problems themselves on the mere basis of their own potentials and capital, as they lack both. Small municipalities depend and will depend on state and other aids. Because of this and because of the principle of sustainable and endogenous development, it is necessary to encourage the creation of municipalities that depend on the state budget as little as possible and that show development self-initiative to the largest extent possible. A more intensive linking of municipalities is indispensable, as together it is easier for them to realise their development projects and compete on the market. Linking is vital, as many municipalities lack funds and educated human resources due to their small size, which is a major hindrance to future development. 